\title{
A Theoretical Analysis of Factors Influencing the Decision of Faculty to Use Educational Technologies in the Context of Institutions of Higher Education
}

\author{
Mohammad Ayub Khan \\ Tecnologico de Monterrey, Mexico \\ Amina Omrane \\ FSEG-Sfax \& Carthage University, Tunisia \\ Adriana Morales Rodríguez \\ Tecnologico de Monterrey, Mexico
}

\begin{abstract}
In this paper we study factors influencing faculty's decision to use educational technologies to support their pedagogical strategies. We briefly describe educational technologies commonly used by faculty to support teaching such as emails, video conferences, chat rooms, video lectures, blackboard discussions and Power Point Presentations for example. We explain in detail faculty factors (i.e., gender, age and cultural background), student factors (i.e., academic performance and gender) and contextual factors (i.e., classroom size, institutional support, course subject, and time constraints) as influential factors in using educational technologies by the faculty to support teaching. The paper findings suggest that the factors under study do influence the faculty decision to use educational technologies to support teaching, however, there are certain strategies education institutions can rely upon in order to overcome the barriers that discourage the faculty to fully integrate technology into their pedagogical strategies.
\end{abstract}

Keywords: Education technology, faculty decision to use technology, higher education, Instructional technology, pedagogical strategies, teaching styles and technology.

\section{INTRODUCTION}

The importance of information and communication technology (ICT) in the evolution and revolution of the modern education system is an undisputable phenomenon. ICT has helped in generating, preserving and disseminating knowledge and at the same time improving human abilities to share knowledge and experiences (Afshari et. al., 2009). ICT helps people access, gather, analyze, present, transmit, and simulate information (See, 1994). ICT creates a learning environment where students deal with knowledge in an active, self-directed and constructive way (Webber, 2003). ICT can develop student's skills for cooperation, communication, problem solving and lifelong learning (Voogt, 2003). Education institutions should prepare students to make effective use of technology which they need in the 21st century (Middleton \& Murray, 1999) not only in the workplace but in all walks of life. For graduates to be successful in the current and more in the future work environment, educational institutions must make technologies of information and communication available to students since most of such technologies are already being used in the business world (Davis, 1989). When refereeing to the educational technologies or pedagogical technologies (i.e., technology used to teach and 
learn) faculty members have a variety of options available for them to support teaching but ironically there certain barriers which limit them to do so (Grasha \& Yangarber-Hicks, 2000).

Over the past several years the emergence and the use of educational technologies have been on the rise (Downing \& Garmon, 2001). This trend has forced universities to increase substantially their investments in educational technologies, technology experts and faculty training as never before. In parallel to the changes brought about by new technologies in the field of education, researchers have become equally concerns about the actual and potential benefits of integrating technological supports (i.e., the use of software, online discussions and chats; Facebook, Twitters, emails, course websites etc.) into other pedagogical strategies such as case studies, research, problem solving and project management (Grasha \& YangarberHicks, 2000). Cuban (1999) is of the view that professors and students are getting used to educational and communication technologies of e-mails and Web pages, but few of the faculty use these technologies for teaching purposes. Even those professors who use technology still face several barriers such as inadequate availability of technology and classrooms that do not support technology (Brill \& Galloway, 2007). Simply using whiteboards instead of chalkboards, PowerPoint instead of overhead transparencies, and electronic communication instead of office hours have implications for the faculty (cultural, work habits, work system) for teachers (Katz, 2006). There can be positive outcomes of the use of technology for educational purposes in many ways. For instances, it can improve communication between the teacher and students (Flanagin \& Metzger, 2001) and thus, enhancing student-teacher interactions (Waldeck, Kearney \& Plax, 2001). Technology can also make it much easier for students to have access to the required educational information cheaply, easily, and timely (Panici, 1998). The use of technology for education purposes may also affects positively student outcomes such as cognitive, behavioral and affective learning (Witt \& Wheeless, 2001). But faculty to a large extent, still resist the full technology-pedagogy integration to this date.

Given the fact that the faculty's resistance to embrace technology fully for teaching purposes is still a big challenge in the educational institutions of higher education, there is the need for a broader and exploratory research to study all those factors which potentially influence the decision of the faculty to fully integrate educational technologies into their pedagogical strategies. Therefore, this particular study is dedicated to the identification and analysis of those factors which influence the faculty to use pedagogical technologies to support teaching. The findings of the study will help the academic leadership of the institutions of higher education to consider those factors while developing curriculum, pedagogical strategies and faculty development programs. Especially, the outcome of the study will be useful when educational technologies are embedded with the existing pedagogical strategies to teach bricks and mortar classroom.

\section{LITERATURE REVIEW}

The literature review focuses technological platforms that are available for the university faculty to choose from as educational technologies (ET) and explains factors influencing the decision of the faculty to use technology for teaching purposes, as shown in figure 1 . The literature review also explains educational strategies (pedagogical approaches) and the integration of educational technologies and educational strategies.

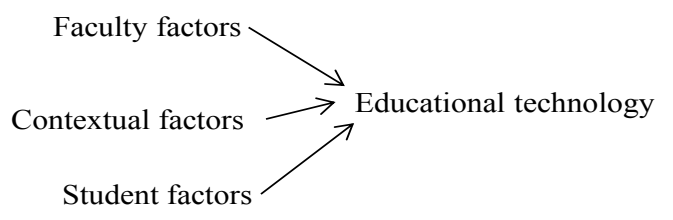

Fig.1: Factors Affecting the Decision of Faculty to Use ET 


\section{EDUCATIONAL STRATEGIES}

Educational institutions are responsible for developing competencies (Knowledge, skills and values) in students who will become future leaders (Alon \& McIntyre, 2005). In order to achieve or fulfill this responsibility educational strategies (pedagogy) require combining different teaching mechanisms ranging from lectures, classroom interactions, case discussions, simulations, experiential methods, team projects, and report writings (Vance, 1993). The pedagogy of education should include action learning model, the critical reflection learning model, the experiential learning model and service learning project (Holman, 2000). Educational strategies should also include finding out an optimal combination of the different teaching styles such as conceptual versus practical, individual versus collective, and under instruction versus via self-study (Boisot \& Fiol, 1987). Ulrich (2005) grouped the educational strategies into four general categories: instructor-centered strategies, interactive strategies, individual-learning strategies, and experiential-learning strategies. The instructor-centered strategies rely on one-way communication where information is provided from the instructor to the students through lecture. Lectures are particularly efficient and effective for large classes and for instruction at the lower levels (knowledge and comprehension) of the cognitive domain (Weston \& Cranton, 1986). Interactive strategies use two-way communication between the instructor and students as well as among students. More importantly, with such approaches students have an opportunity to participate actively in the learning and teaching processes. Interactive strategies include small group discussions, cooperative learning, group projects, argumentative discussion, large-class discussion, and seminars (Ulrich, 2005). Individual-learning strategies allow students to learn at their own pace through regular immediate feedback in order to assess their progress. Individual-learning strategies are examinations-in-general, problem examinations, term papers, homework, required readings, and thinking alone (Ulrich, 2005). The experiential-learning strategies are active learning because students take an active role in reaching the more complex educational outcomes of application, analysis, synthesis, and evaluation (Chickering, 1977). Experiential-learning strategies include: internships, management simulation, role playing, structured experiential exercises, videos, case analyses, and case studies (Ulrich, 2005). Any of these teaching and learning strategies, if supported appropriately and adequately by the use of educational technology, the purpose of education, which is graduating students with competencies in their respective fields and disciplines (knowledge, abilities and values) needed in the society and industry, is possible to achieve.

\section{EDUCATIONAL TECHNOLOGIES}

Defining the term educational technology (also known as instructional technology) is difficult since there is a need to distinguish between educational technology as a theory and as a field of practice and to focus on either the process or the system approaches (Al-Ammary, 2013). The educational technology is defined as solutions to instructional problems involving social as well as machine technologies in order to improve the effectiveness and efficiency of learning in the context of education (Gentry, 1995). The educational technology is also considered as means of media with four different focuses: media for enquiry (i.e., data modelling, spreadsheets, hypertext, etc.); media for communication (i.e., e-mail, graphics software and simulations); media for construction (i.e., robotics, CAD, control systems), and media for expression such as interactive video, animation software, music composition (Bruce \& Levin, 1997). Many in the education industry view education technology as a tool for improving the presentation of material for making lessons more fun for the learners and for making administration more efficient (Cox et al., 1999). Furthermore, education technology is defined as "the study and ethical practice of facilitating learning and improving performance by 
creating, using and managing appropriate technological processes and resources (Richey, 2008)". Educational technologies are also defined as the theory and practice of design, development, use, management, and evaluation of processes and resources for learning (Richey, 2013). Educational technologies are the hardware and software packages that provide a mechanism for delivering instruction and needed instructional support for teachers and students (Rice \& Miller, 2001).

The educational technology is useful both for the educators and educational administrators. The emergence of different educational tools and software has motivated educational institutions to integrate them into the educational strategies (Hawkins et al., 1996). Educational technologies are considered crucial for improving the quality of education in general and enhancing the level of student learning performance (Bialo \& Sivin-Kachala, 1995) in particular. Technology has solved the problem of distance, time and finance and created a situation where effective and productive learning philosophies got grounds. Higher education's competitiveness will increasingly require that it serve society's needs and the enablement of its missions through information technology and that the campus of the future will embody distributed learning (Oblinger \& Maruyama, 1996). Educators and policy leaders are envisioning new approaches to instruction based on communications and computer technology using learning on demand and learner-centered instruction (Twigg \& Oblinger, 1997).

Faculty members have a wide range of educational technologies available for them to use in support of the traditional methods of teaching (Boose, 2001). For example, instructors may use PowerPoint presentations, or organize video conferences in order to bring guest lecturers from distant places into the classroom or simply using YouTube lectures to support class lectures. Faculty can also use other computer-based technologies such as electronic mail, Web pages, chat rooms, and electronic bulletin boards to facilitate communication with the students (Driver, 2002). Social networks such as Facebook, Twitter and LinkedIn are also popular among the young generation to share information and communicate interactively. A number of other teaching software, online exercises, interactive televisions and computer simulations are available for faculty members to use (Seay et al., 2001). Table 1 provides a list of information and communication technology tools used in teaching and learning in educational institutions of all categories and sizes (Thieman, 2008).

Table 1: List of ICT to use as Educational Technologies

$\begin{array}{lll}\text { LCD Projector } & \text { Word Processing } & \text { Computer Games } \\ \text { DVD/Streaming Video } & \text { Internet Search Tools } & \text { Digital/video Cameras } \\ \text { Tape/CD player } & \text { Graphic Organizers } & \text { CD's of student work } \\ \text { Graphics Clip/Art } & \text { Web-quests } & \text { Spreadsheet } \\ \text { CD-ROM } & \text { Webpage/Class websites } & \text { Power Point } \\ \text { Smart Board } & \text { Subject specific software } & \text { Web Log } \\ \text { I-Movie } & \text { Podcasts } & \text { Email } \\ \text { Photo Shop } & \text { Simulations } & \end{array}$

\section{Integration of Educational Technologies and Educational Strategies}

The use of educational technology in support of teaching enhances learning and benefits students (Kim \& Hannafin, 2011). However, most teachers do not fully and effectively integrate technology into teaching strategies (Gorder, 2008) rather they only use educational technology to design instructional materials or deliver lectures (Tondeur, van Keer, van Braak, \& Valcke, 2008). The faculty has a variety of technology options to select from to support their particular 
teaching strategy. Also, faculty has the option to use the technology according to their needs and interests starting from the basic uses (power points presentations and sending emails for example) to the very advanced or well-integrated level (online learning). In any of these levels of technology-pedagogy integration, it is important that two basic educational elements which are content and pedagogy (teaching and learning) must be assisted by the use of educational technologies, not otherwise (Earle, 2002). Educational technologies should be a hindrance neither for the teacher nor for the students (Earle, 2002). An effective and purposeful integration of educational technologies and educational pedagogy must encompass (Tondeur, van Keer, van Braak, \& Valcke, 2008):

1. Encouraging collaborative learning through information search on the Internet and sharing information.

2. Using computers for differentiating and creating learning activities.

3. Encouraging students to improve their skills (i.e., information literacy and management).

4. Requiring students to conduct research projects and other learning activities using computer and computer related technologies.

5. Using computer as a pedagogical platform (i.e., instruction and demonstration tool).

6. Teaching students about the possibilities and potentials of computer use.

Educational technologies should encourage students to participate in learning tasks, including collecting, analyzing, and presenting information (Niederhauser \& Stoddart, 2001). The integration of educational technologies into pedagogical strategies should go beyond only facilitating student development of conceptual understanding through instructional processes to active teacher-student engagement in learning through learner-centered teaching approaches using for example, project-based learning and collaborative learning (Inan, Lowther, Ross, \& Strahl, 2010). Existing studies (i.e., Yen \& Lee, 2011) show that students using technology for classroom group discussions and report writings perform better in terms of learning achievements (academic performance) than those students who do not use technology for learning purposes. Instructors using technology to support their teaching ought to act as coaches, facilitators, mentor and guide (constructivist approach) rather than acting like traditional lecturers (instructor-centered teaching). Students should be allowed to use indepth questioning to acquire information, work in small groups, interact and develop their verbal and social skills (Nussbaum et al., 2009).

\section{Factors Influencing Faculty's Decision to use Educational Technology}

Well integrated pedagogy-technology educational system and culture is fundamental for the provision of quality education now and in the future. Since, educational technologies are the recent inventions, adoption of which by the faculty to support their teaching demands a gradual approach and creative-conducive work environment. It is also important to identify and study those factors which influence or might influence positively or negatively the decision of the faculty to use educational technologies. As suggested earlier the term educational technologies or ICT refers to computers and the associated hardware, networks, and software used and could be used for teaching and learning purposes. The use of educational technologies to support teaching can be affected by several factors such as social contexts and appreciations of usefulness of technology in teaching (Zare-ee, 2011). Factors like lack of necessary resources for the faculty and negative attitudes and beliefs of the faculty are also found some of the main causes for the insufficient technology-pedagogy integration (Park \& Son, 2009). Ertmer (1999) identified and categorized barriers which influence the decision of faculty to use technology as external (lack of equipment, insufficient training and lack of on 
time-technical support) and internal (teacher beliefs and attitude) barriers. Several other factors influencing the adoption and integration of ICT into teaching have been identified by researchers. For example, Stockdill and Moreshouse (1992) identified user characteristics, content characteristics, technological considerations, and organizational capacity as factors influencing ICT adoption and integration into teaching. Balanskat, Blamire \& Kefalla (2007) identified the factors as teacher-level, school-level and system-level. Teachers' integration of ICT into teaching is also influenced by organizational factors, attitudes towards technology and other factors (Chen, 2008). Sherry \& Gibson (2002) claim that technological, individual, organizational, and institutional factors should be considered when examining ICT adoption and integration. Neyland (2011) found factors such as institutional support as well as micro factors such as teacher capability of using computer and computer related programs influencing the use of online learning. Ahadiat (2005) added ethnicity, rank, sub-areas, as influential factors in using instructional technology by the instructors. Teachers' characteristics (e.g. individual's educational level, age, gender, educational experience, experience with the computer for educational purposes and financial position) were found influencing the adoption of an innovation (Schiller, 2003) or new system of work. In addition, Bauer and Kenton (2005) found that students' factors such as they did not have enough time to go to computer labs or work with computers and teachers needed extra planning time for technology lessons. Other concerns were outdated hardware, lack of appropriate software, technical difficulties, and student skill levels affect the use of educational technologies at school. According to Carvin (1999) “The teacher's own learning style is certainly one such factor. For example, if a teacher is a creative thinker who likes the idea of constructing knowledge, is a life-long learner, a social learner, and a decision maker, he may be more likely to use computers in more integrative and transformational ways that are useful and valuable to students instead of ways that promote and support traditional classroom practices".

Table 1 list factors that influence faculty decision to use educational technologies to support teaching and learning (Medlin, 2001; Al-Bataineh et al. 2008; Yildirim 2007; Frederick, Schweizer \& Lowe 2006; Goktas, Yildirim \& Yildirim 2009; Lim \& Chai, 2008; Fu, 2013; IniestaBonillo et al., 2013; Cooper, 2006; Peluchette \& Rust, 2005):

\section{Table 2 List of Factors Influencing Faculty Decision to Use Educational Technology}

Pedagogical support
Skills for managing teaching materials
Software competence
Excessive focus on teaching technical or operational
skills rather than course content
In-service training on the use of ICT
Technical problems in the classroom
Uncertainty about the possible benefits of using ICT
in the classroom
Lack of specific direction
Faculty gender
Area of expertise of faculty
University of origin of faculty
Student factors
Institutional factors
Technology related factors
Faculty experience
Individual culture

Reward system

Mandate \& recognition

Class Size

Course/subject nature

Resources (time and money)

Student abilities

Problems with technology

Infrastructure

Need for the technology

Technical support and facilities

Teaching experience with ICT

Availability of enough computers

Time constraints

Social pressure

Personal interest

Individual behavior

Teacher expectations

Clear goals for ICT use

Other human factors such as individual feelings of anxiety, fears, preferences and perceptions, feelings of competence, and teaching styles and strategies of the professor have also been 
correlated with the decision of using instructional technologies (Dusik, 2000). Robertson et al (1996) argued that teachers' resistance to computer use was divided into several broad-based themes: resistance to organizational change; resistance to outside intervention; time management problems; lack of support from the administration; teachers' perceptions; personal and psychological factor. Researchers (Osika, 2006) are of the view that if proper and early attention is given to these diverse beliefs and competencies of the faculty, there will be a strong likelihood that the faculty will opt for integrating instructional technologies into their teaching strategies.

Given the fact that there are diverse and multidimensional factors that influence or can influence the decision of the faculty to use educational technologies in their classes, this paper focuses on factors as shown in Figure 2:

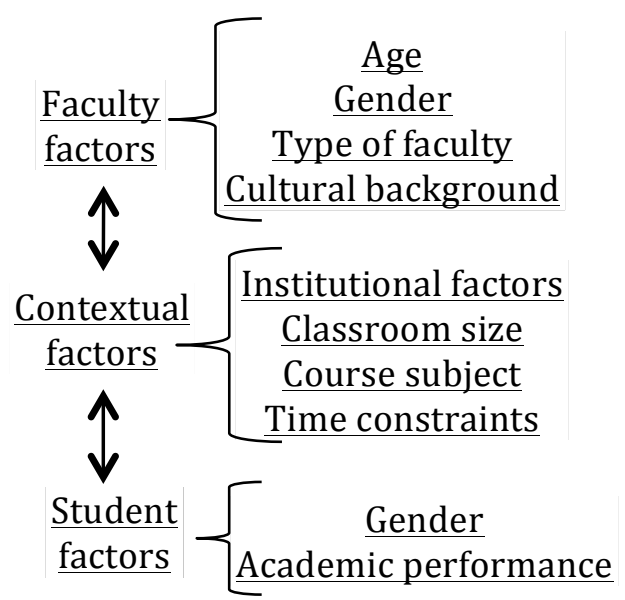

Fig.2: Faculty, Contextual and Student Factors Influencing the Use of Educational Technologies

Faculty Factors: Faculty factors including individual's educational level, age, gender, educational experience, and experience with the computer are found to influence the adoption of an innovation (Schiller, 2003) or innovative system such as instructional technologies. For example, faculty members with fewer years of experience are more likely to use computers in their classes than teachers with more years of experience (National Center for Education Statistics, 2000). This is possible due to the fact that the faculty is new to use the computer and generally new faculty members are provided training to use computers as a part of their orientation programs. The age factor of the faculty is found to be an influential factor as well in the decision-making process of whether to integrate educational technologies into teaching strategies. Faculty who are in the middle or later stages of their careers can resist the use of instructional changes since tenured faculty may not be compelled to use technology and senior faculty may not have the knowledge or required training to use the educational technology (Peluchette \& Rust, 2005). Other studies found that different types of faculty view differently the use and importance of technology for teaching purposes. Al-Bataineh and Brooks, (2003) identified these 5 different types of faculty and their corresponding characteristics in relation to the computer efficacy and the use of educational technology for teaching purposes:

1. Knowledge-level teachers aware of computers and may be users or non-users. They are capable of following well-written key-by-key directions.

2. Application-level teachers are willing to use or allow students to use applications, but leave instructional control with the software.

3. Analysis-level teachers are capable of extracting portions of applications to assist in student achievement of identified curriculum objectives. 
4. Synthesis-level teachers merge classroom instruction, relevant on-line instructional techniques and supplementary materials.

5. Evaluation-level teachers create and appraise classroom opportunities for learning beyond the design of instructional software and accompanying curriculum materials.

The relationship between gender and the use of technology is a popular discussion within the research community. For example, women's use of the telephone for socialization purposes helped expand this usage in both residential and business areas (Martin, 1991). The importance of gender and technology association study is encouraged since it is important to learn how new technologies are evaluated through the lens of an existing gender system (Hopkins, 1998; Hopkin, 1997). There are emotional, psychological, social reasoning behind the differing views of men and women of the use of computers in personal and professional life. There are differences on how do men and women view the world. Men tend to see the real world as a hierarchical structure whereas women tend to view it as an interconnected web of people (Gilligan, (1982). Therefore, for example, e-learning, which integrates computer and communication technology, might affect men and women differently because of the communication patterns adopted by them (Heinich et. al., 1996). In another study, women and men were found to have different beliefs of usefulness and the ease of use of email (Gefen \& Straub, 1997). According to Spotts (1997), male faculty members tend to rate their knowledge and use of technology higher than their female counterparts. However, female instructors take factors such as lack of time and lack of professional advancement into consideration when deciding whether or not to integrate technology into the curriculum. Additionally, Lumpe and Chambers (2001) argue that female instructors believe that factors such as administrators, students, equipment, and professional development, directly influence a person's ability to be successful with technology. Gender differences are also found in adopting new software systems where men technology acceptance is affected by their perception of usefulness, while women are influenced by perceptions of ease of use and subjective norms (Venkatesh \& Morris 2000).

Moreover, studies on the cultural background of the faculty have shown that the individual cultural backgrounds can be a driving force when accepting a change or a new work system in the workplace. In the education field, socio-cultural background of faculty can be an influential factor in accepting or rejecting the use of a particular instructional technology (Cuban, Kirkpatrick, \& Peck, 2001; Huang, 1997. For example, a study (Zare-ee, 2011) on education issues in Turkey finds that oral tradition and patronage system combined with the rote memorization and the sacredness of the text, make online textbook less suitable. Also, in societies where interpersonal relationship with relatives, family and neighbors is superior to individual independence and self-reliance, faculty will tend to prefer face-to-face and more personalized teaching and learning strategies (Zare-ee, 2011). In cultures where teachers use textbook as a source the primary source of knowledge and consider correct answers or high scores on paper-pencil tests when assessing learning success (Lee, 2009) may not opt for the use of online or computer-based exams for example. Similarly, in cultures where teachers are expected to cover the textbook of the course as a whole as a source of good academic achievements and performance leading students to high school or university entrance (admission), faculty members tend to cover the textbook content to guide student learning and thus affecting the use technology (C.-H. Chen, 2008). Computer based collaborative works at student and classroom levels have also been shown to affect the role of teachers and expectations of the learners and thus creating a new dynamic of teaching-learning environment (Damarin, 1998). Other researchers (i.e., Reeves \& Reeves (1997) foresee the core pedagogical values might be considered appropriate in one culture but inappropriate in 
another, for example, "the expectation that students will question knowledge, or challenge the teacher's view". More so, "when teachers are overly concerned with academic achievement and skill-based knowledge, and teach textbook content only, or identify with the examinationoriented education culture, technology integration would be insufficient and lack meaningful practices; this may be related to an inadequate understanding of technology integration (Liu, 2010)". Therefore, Henderson (1996) suggested that instructional design models must include cultural contextuality in addition to the cognitive, social and pedagogical issues and "instructional design is about the creation of cultural identity and cannot be culturally neutral".

Contextual Factors: The contextual factors that influence or might influence the decision of the faculty to use educational technology for teaching purposes include institutional factors, classroom size, course subject, and time constraints. Institutional factors include a wide range of factors such as faculty development programs, ease of access to use technology, policies and procedures, and support for technological (Osika, 2006). Institutional support include accessibility; technical support; leadership support; professional development, teaching workload; teaching experience (Buabeng Andoh, 2012). The role of the classroom size assigned to the faculty as a contextual factor is also important in the implementation of educational technologies by the faculty. For example, when faculty members use technologies such as email and chat rooms, large classes can be difficult to manage, especially when teaching an online course (Peluchette et. al., 2005). Though there is no answer to the question of what is the ideal size of the class (Kelly \& Maushak, 2004), pedagogically it is relatively easier for the faculty to work with a small size classroom when implementing new technology or pedagogical strategies (Maushak, Kelley \& Blodgett, 2001).

Another contextual factor which is the course subject (or the course taught by the faculty) is also influences the choice of technology used to support the learning experience. Related variables such as the learning objectives of the course, textbook and other course materials to be used for teaching (Mumtaz (2000) are also important to consider. For example, faculty teaching soft subjects like strategic management and marketing courses may use computer and related software in class to carry out simulation and other group dynamics. But faculty teaching more quantitative and complex courses (i.e., from engineering and medical fields) tend to depend more on traditional pedagogical strategies in order to interact more directly with the students. On the top of these contextual factors described above, lack of time (time constraints) has been found one of the critical factors in influencing the decision of the faculty when using technology to support teaching (Mumtaz, 2000). Lack of time includes both the release time and the scheduled time (Mumtaz, 2000) where both the lack of release time and the scheduled time are found not allowing faculty to use computers in their classes, prepare materials for their classes and practice computers and software. For course development, course management and technology related training faculty requires sufficient time (Bocchi et al., 2004) out of their regular workload. "Teacher's time committed to teaching and amount of technology training are reliable factors of technology use in classroom (Vannatta \& Fordham (2004)".

Student Factors: Students factors including academic performance of students, gender, age, academic background, professional experience, ethnicity, socio-economic conditions, nationality and computer self-efficacy are influential factors in the decision of faculty to use instructional technologies in their courses/classes (C-H. Chen, 2008). However, this paper focuses on the academic performance and gender of students for further elaborations. In fact, the pedagogy-technology integration should promote active learning and thus benefiting 
students by improving their learning and academic achievements (Liu, 2007). For such an active learning to happen, students must participate actively in the learning process and perform well academically. Li (2007) wrote "that if teachers had poor students or were teaching unfamiliar subjects, technology use was not considered, even when teachers understood that students favored technology and technology was the preferred means of acquiring information". In addition to the academic performance of students, the role of gender (female vs male students) of students is also an important criterion for the faculty to use educational technologies. Historically the use of technology is considered as being a male activity (Wajcman, 1991). A study on the gender issue by Shashaani (1995) finds that male students have not only interest in learning and using computers but they also receive encouragement to use computers. Another study of Macleod, Haywood \& Haywood (2002) suggests that female students are relatively more apprehensive about computer use and view technology more favorably than their male counterparts (students). Contrastingly, some other studies find that females generally feel more anxiety and less experience with technology than males (Ayersman \& Reed, 1995). "Males typically have lower computer anxiety and higher computer interest than females (Schumacher \& Morahon, 2001)".

\section{DISCUSSION AND CONCLUSION}

The information and communication technologies have brought dramatic and revolutionary changes in all walks of life of human societies and more notably in our education system (Buabeng-Andoh, 2012). Technology has affected and is affecting at the skyrocketing speed the workplace, business and business management, organizations and our individual life. In response to such trends and tendencies our schools and universities are expected to reorganize and reorient their educational programs and services including curriculum and pedagogical strategies. The gap between teaching and learning must be bridged through an effective adoption of the advances in the educational technologies in order to provide learners with knowledge of specific subject areas, to promote meaningful learning and to enhance professional productivity (Tomei, 2005). One must consider the potential benefits of the use of educational technologies to support pedagogical strategies as listed by Becta, (2004): Increased academic achievements; encourages student's collaboration; improves student's communication and interpersonal skills (e.g., ability to be a group member); increase the competency among other academic staff; give the teachers the opportunity to be learning facilitators instead of information providers. Reduce the pressure of the lecture preparation on the instructor; make the content and delivered materials of the lectures clearer; helps the students to remember the information easily; increases the interaction between students; and, enhances the students' ability to work in a group.

However, a number of factors associated with the faculty, institution, and student make it difficult for the educational technologies to be well- integrated into the existing teaching and learning strategies in the institutions of higher education (Bauer \& Kenton, 2005). Teacherlevel barriers include lack of teacher ICT skills; lack of teacher confidence; lack of pedagogical teacher training; lack of follow-up of new and lack of differentiated training programs. Faculty factors include beliefs about what (content) and how (pedagogy) to teach and skills including classroom management, teaching skills and computer handling. Also, matching the instructional technology with pedagogy used in teaching a particular subject is an influential factor in the decision of the faculty to use educational technology (Franklin, 2007). Other factors such as feelings, knowledge and attitudes of the faculty influence the use of educational technologies in teaching (Huang \& Liaw, 2005). Moreover, faculty perception of the use of technology as better than previous practice; consistent with their existing values, past experiences and needs; ease to use, can be experimented with on a limited basis before making 
a decision to adopt and finally the results of the innovation are visible to others (Keengwe \& Onchwari, 2008). Institutional factors such as technical support, funding, training and facilities influence faculty adoption and integration of technologies into their classrooms (Wozney et al., 2006). The school-level barriers comprise absence of ICT infrastructure; old or poorly maintained hardware; lack of suitable educational software; limited access to ICT; limited project-related experience; lack of ICT mainstreaming into school's strategy and the systemlevel barriers include rigid structure of traditional education systems; traditional assessment; restrictive curricula and restricted organizational structure. Knowing the extent to which these barriers affect individuals and institutions may help in taking a decision on how to tackle them (Becta, 2004). The general perception felt on campus among the faculty and students alike is that the computers and related technologies are logistical burdens and barriers for the effective teaching and learning in that both faculty and students spend time in learning how to use the technology. Technological platforms are changing without giving the faculty and student enough time learn and take fully advantage from one technology before opting for adopting a new one (Plair, 2008).

\section{RECOMMENDATIONS AND IMPLICATIONS}

As concluded that the educational technologies are parts and parcels of the education system and there is no way to deny the use of educational technologies in one way or the other. Nonetheless, it is also concluded that there is still resistance from different forces within and without the education institutions to fully integrate educational technologies into the regular pedagogical strategies across the board. Therefore, herewith a number of practical recommendations are put forward for the educational institutions and their leadership to pursue while trying or wanting to adopt educational technologies to support pedagogical strategies. (1) Faculty attitude must be changed from negative to positive towards technology and the uses of technology for teaching purposes. They must be assured that technology will make their teaching interesting, easier, fund, motivating and enjoyable (Bruce \& Levin, 2001). (2) Faculty should be made aware that the use of technology in teaching is helpful for the students alike since it encourages inquiry, helping communication, constructing teaching products, and assisting students' self-expression (McCannon \& Crews, 2000). (3) The issue of the use of technology and its usefulness must be part of programs of faculty development and when discussing instruction, education, or training issues (Snelbecker, 1999). (4) Faculty perception of the usefulness of the technology should be improved and the constraints of selfefficacy and structure must be removed (Buchanan et al., 2013). (5) Educational institutions must remove or at least reduce the barriers: Lack of time to integrate educational technology in teaching activities; lack of funding to purchase the equipment and software needed; insufficient computing infrastructure (servers, bandwidth, storage capacity; Insufficient computing facilities (labs, technology-equipped classrooms; not enough training offered in the areas that interest you; not enough assistance with technical problems; not interested in using technology (Fu, 2013). (6) Provide trainings and workshops related to technology to update teachers' skills and knowledge (Al-Bataineh et al. 2008). (7) Support partnerships that help teachers share effective technology practices and experiences (Ertmer \& Otternbreit-Leftwich 2010). (8) Augment curricula with technology-enhanced materials (Goktas, Yildirim \& Yildirim 2009). (9) Provide enough freedom for teachers in selecting and covering curriculum material (Honan 2008). (10) Provide adequate technical support to the faculty and students (Liu \& Szabo 2009).

However, the implementation task of such recommendations is not without limitations (Gilakjani, 2013). Firstly, the use of instructional technology alone does not guarantee the 
effective use of the technology for teaching purposes. Secondly, there is need for proper planning, implementing and evaluating the technology-pedagogy integration work. The use of technology in teaching should enhance both the quality and productivity of the education services provided to students. Achieving optimal conditions for faculty, students and the institution to integrate and maintain the technology-pedagogy integration is pivotal. It demands time, money, culture and strategy from the academic leaderships. It is also imperative to provide enough time, financial assistances, technical help and pedagogical guidance to the faculty in order to design teaching activities and experiences supported by technology; implement such activities as planned and assessing the effectiveness of technology based teaching. Thirdly, as suggested by researchers in the field (i.e., Gilakjani, 2013), faculty will have to understand and be responsible for the social, ethical, legal, and human issues in connection with the technology-pedagogy integration. Fourthly, exercising extreme patience from all the concerned corners is needed since integrating technology-pedagogy fully and truly is a slow and time-consuming process and task (Collins, 1997). Fifthly, continuous collaboration from and good communication among the institutional leadership, faculty, students, technology support center and pedagogical specialists will enable the technologypedagogy integration process and system to function smoothly and properly. For this to happen, all relevant stakeholders need to meet regularly to share best practices and on time information (Usun, 2005). The technology-pedagogy integration management should include faculty evaluation and feedback on how did they use technology in their classes and the impact of the same on their teaching effectiveness (Dahlstrom, 2015). Sixthly, it is also a cumbersome task to identify and match differing variables such as new advances in educational technologies, nature of the course, learning outcomes of the course, lecture type and materials, students learning styles and professors' teaching styles (Trucano, 2005). Additionally, institutions of higher education must make the adoption of new technologies to support pedagogical strategies, an important component of the institutional strategic planning. Seventhly, and finally, the macro environment (society, industry and technology) surrounding organizations is constantly changing and thus demanding for permanent need assessment methods, change strategy, new organizational system (Balash et al., 2011), culture and strong leadership.

\section{LIMITATIONS AND FUTURE STUDIES CONSIDERATIONS}

This study is an exploratory one and therefore, is based on the literature review that exists on the issue of factors influencing the faculty decision to use educational technologies to support pedagogical strategies. The study provides a theoretical foundation and understanding of the issues facing educational institutions in implementing new educational technologies. Research methodologists appreciate the role of literature review based studies in establishing the need for further research while broadening the horizons of the researcher and preventing the researcher from conducting research that already exists (Aitchison, 1998; Khan \& Law, 2015). Furthermore, literature review based studies helps the researcher and readers to be knowledgeable and understand the research problem better (Leedy, 1989). Furthermore, literature review based studies are also helpful in establishing theoretical grounds for research, identify gabs in the existing knowledge and weaknesses in previous research, discovers connections or other relations between different research results by comparing various investigations (Bless \& Higson-Smith, 2000; Khan, Law, 2015). However, this is a descriptive study involving a type of document analysis and secondary research based on textual information. Some researchers question the validity and reliability of recommendations of such studies since the origin of the information needs scrutiny and critical evaluation (Khan \& Law, 2015). Future studies on factors influencing the faculty decision to use educational technology to support teaching strategies should involve quantitative analysis using 
independent (faculty factors), dependent (use of instructional technology) and moderating (student and institutional factors) variables as shown in Figure 3:

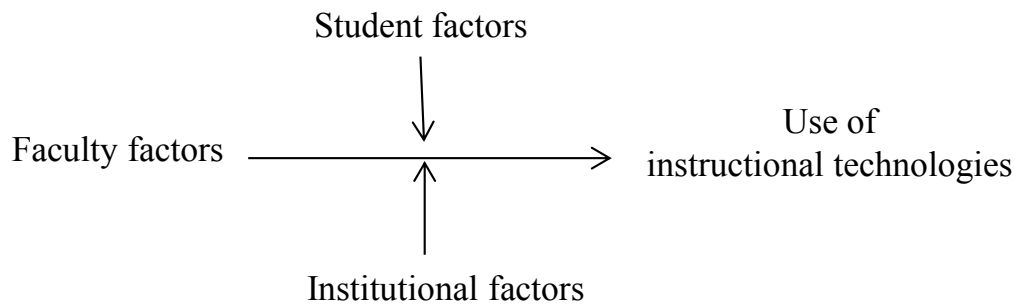

Figure 3 Factors influencing the faculty decision to use educational technologies

\section{References}

Afshari, M., Abu Bakar, K., Luan, W. S., Abu Samah, B., \& Fooi, F. S. (2009), 'Factors Affecting Teachers' Use of Information and Communication Technology, 'International Journal of Instruction, 2(1), Retrieved from www.eiji.net

Ahadiat, N, (2005), 'Factors that May Influence or Hinder Use of Instructional Technology Among Accounting Faculty,' Retrieved form http://ssrn.com/abstract=2384936

Aitchison, J. (1998), 'Access to Books and Journal Articles by Post-Graduate Students on a Course-Work master's program in information studies at the University of Natal, Pietermaritzburg (Unpublished MIS Thesis), University of Natal, Pietermaritzburg.

Al-Ammary, J. (2013), 'Educational Technology: A Way to Enhance Student Achievement At The University Of Bahrain,' The Online Journal of New Horizons in Education, 7(3): 54-65.

Al-Bataineh, A. \& Brooks, L. (2003), 'Challenges, Advantages, and Disadvantages of Instructional Technology in the Community College Classroom,' Community College Journal of Research and Practice, 27: 473-484, 2003

Al-bataineh, A., Anderson, S., Toledo, C. \& Wellinski, S., (2008), 'A study of technology integration in the classroom,' International Journal of Instructional Media, 35, 381-387.

Alon, I. \& McIntyre, J. R. (2005), 'Business and Management Education in China : Transition, Pedagogy and Training, World Scientific Publishing Co. Pte. Ltd. Singapore

Ayersman, D., \& Reed, W. M. (1996), 'Learning Styles, Programming and Gender on Computer Anxiety,' Journal of Research on Computing in Education, 28, 148-161.

Balanskat, A., Blamire, R., \& Kafal, S. (2007), 'A review of studies of ICT impact on schools in Europe,' Retrieved from European Schoolnet.

Balash, F. Yong, Z. \& Bin Abu, B. (2011), 'Lecturers and educational technology: Factors affecting educational technology adoption in teaching, 2nd International Conference on Education and Management Technology IPCSIT, Vol. 13, Singapore.

Bauer, J., \& Kenton, J. (2005), 'Technology integration in the schools: Why it is not happening,' Journal of Technology \& Teacher Education, 13, 519-526.

Becta (2008), 'Harnessing Technology: Schools Survey 2008,' Retrieved October 20, 2011 from http://emergingtechnologies.becta.org.uk/uploaddir/downloads/page_documents/reearch/ht_schools_survey08 _analysis.pdf/.

Becta. (2004), 'A review of the research literature on barriers to the uptake of ICT by teachers,' Retrieved from http://partners.becta.org.uk/page_documents/research/barriers.pdf.

Bialo, E. R. \& Sivin-Kachala, J. (1995), 'Report on the Effectiveness of Technology in Schools, 95-96. Washington, D.C.: Software Publishers Assn.

Bless, C., \& Higson-Smith, C. (2000), 'Fundamentals of social research: An African perspective (3rd ed.),' Cape Town: Juta.

Bocchi. J.. Eastman, J., \& Swift, C. (2004), 'Retaining the online learner: A profile of students in an online MBA program and implications for teaching them,' Journal of Education for Business, 79(4): 245-253. 
Khan, M.A., Omrane, A., \& Rodriguez, A. M. (2017). A Theoretical Analysis of Factors Influencing the Decision of Faculty to Use Educational Technologies in the Context of Institutions of Higher Education. Advances in Social Sciences Research Journal, 4(1) $147-164$.

Boisot, M.H. \& Fiol, M. (1987), 'Chinese boxes and learning cubes: action learning in a cross-cultural context,' Journal of Management Development, 6(2): 8-18.

Boose, M. (2001), 'Web-based instruction: Successful preparation for course transformation,' Journal of Applied Business Research, 17(4): 69-81.

Brill, J. M., \& Galloway, C. (2007), 'Perils and promises: University instructors' integration of technology in classroom-based practices,' British Journal of Educational Technology, 38(1): 95.

Bruce, B., \& Levin, J. (2001), 'Roles for new technologies in language arts: inquiry, communication, construction, and expression,' In J. Jenson, J. Flood, D. Lapp, \& J. Squire (Eds.), the handbook for research on teaching the language arts. NY: Macmillan.

Bruce, B.C., \& Levin, J.A. (1997), 'Educational technology: Media for inquiry, communication, construction, and expression,' Journal of Educational Computing Research, 17(1): 79-102. Retrieved from http://www.lis.uiuc.edu/ chip/pubs/taxonomy/index.html.

Buabeng-Andoh, C. (2012), 'Factors influencing teachers' adoption and integration of information and communication technology into teaching: A review of the literature, International Journal of Education and Development using Information and Communication Technology, IJEDICT, 8(1): 136-155.

Buchanan, T., Sainter, P., \& Saunders, G. (2013), 'Factors affecting faculty use of learning technologies: implications for models of technology adoption,' Journal of Computing in Higher Education, 25 (1), 1-11.

Carvin, A. (1999). Technology Professional Development for Teachers: Overcoming a pedagogical digital divide,' The Digital Beat, 1(16): 1-5. Retrieved from: http://www.benton.org/DigitalBeat/db093099.html.

Chen, C.-H. (2008), 'Why do teachers not practice what they believe regarding technology integration? The Journal of Educational Research, 102(1): 65-75.

Chickering, A. W. (1977), 'Experiential learning. New Rochelle, NY: Change Magazine Press.

Collins, D. (1997), 'Achieving Your Vision of Professional Development: How to Assess Your Needs and Get What You Want. Tallahassee, FL: SERVE.

Cooper, J. (2006), 'The Digital Divide: The Special Case of Gender,' Journal of Computer Assisted Learning, 22(5): 320.

Cox, M., Preston, C. \& Cox, K. (1999), 'What Factors Support or Prevent Teachers from Using ICT in their Classrooms? Paper presented at the British Educational Research Association Annual Conference, University of Sussex, Brighton.

Cuban, L., Kirkpatrick, H., \& Peck, C. (2001), 'High access and low use of technology in high school classrooms: explaining an apparent paradox,' American Educational Research Journal, 38(4): 813-834.

Dahlstrom, E. (2015), 'Educational Technology and Faculty Development in Higher Education. Research report,' Educause. Retrieved from http://www.educause.edu/ecar.

Damarin, S. K. (1998), 'Technology and multicultural education: The question of convergence,' Theory into Practice, 37(1), 11-19.

Davis, F. D. (1989), 'Perceived usefulness, perceived ease of use and user acceptance of information technology,' MIS Quarterly, 13(3), 319-339.

DeVoogd, G. L. (1998), 'Computer use and power sharing: multicultural students' styles of participation and knowledge,' Computers and Education, 31, 351-364.

Downing, J., \& Garmon, C. (2001), 'Teaching students in the basic course how to use presentation software,' Communication Education, 50, 218-229.

Driver, M. (2002), 'Investigating the benefits of Web-centric instruction for student learning: An exploratory study for an MBA course,' Journal of Education for Business, 77 (4): 236-246.

Dusick, D. M., \& Yildirim, S. (2000), 'Faculty computer use and training: Identifying distinct needs for different populations,' Community College Review, 27(4): 33.

Earle, R. (2002), 'The integration of instructional technology into public education: promises and challenges,' ET Magazine, 42(1): 5-13. 
Ertmer, P. A. (1999), 'Addressing first- and second-order barriers to change: strategies for technology integration,' Educational Technology Research and Development, 47(4): 47-61.

Ertmer, P. A., \& Otternbreit-Leftwich, A. T., (2010), 'Teacher technology change: How knowledge, confidence, beliefs, and culture intersect, Journal of Research on Technology in Education, 42, 255-284.

Flanagin, A. J., \& Metzger, M. J. (2001), 'Internet use in the contemporary media environment,' Human Communication Research, 27, 153-181.

Franklin, C. (2007), 'Factors that influence elementary teachers use of computers,' Journal of Technology and Teacher Education, 15(2): 267-293.

Frederick, G. R., Schweizer, H., \& Lowe, R., (2006), 'After the in service course: Challenges of technology integration,' Computers in the Schools, 23, 73-84.

Fu, J. S. (2013), 'ICT in Education: A Critical Literature Review and Its Implications,' Communications Technology - a 10 year study of new undergraduates, Techtrends, 46(6): 11-15.

Gefen, D. \& Straub, D.W. (1997), 'Gender differences in the perception and use of E-mail: An extension to the technology acceptance model,' MIS Quarterly, 21(4), 389.

Gentry, C. G., (1995), 'Educational technology: A question of meaning. In G. Anglin (Ed.), Instructional technology: Past, present, and future, Englewood, CO: Libraries Unlimited.

Gilakjani, A. P. (2013), 'Factors Contributing to Teachers' Use of Computer Technology in the Classroom,' Universal Journal of Educational Research, 1(3): 262-267. Retrieved from http://www.hrpub.org.

Gilligan, C. (1982), 'In a different voice: Psychological theory and women's development,' Cambridge, MA: Harvard University Press.

Goktas, Y., Yildirim, S., \& Yildirim, Z. (2009), 'Main barriers and possible enablers of ICT integration into preservice teacher education programs,' Educational Technology and Society, 12, 193-204.

Gorder, L. M. (2008), 'A study of teacher perceptions of instructional technology integration in the classroom,' Delta Pi Epsilon Journal, 50(2), 63-76.

Grasha, A. F., \& Yangarber-Hicks, N. (2000), 'Integrating teaching styles with instructional technology. College Teaching, 48(1): 2-10.

Hawkins, J., Panush, E., \& Spielvogel, R. (1996), 'National study tour of district technology integration (summary report), New York: Center for Children and Technology, Education Development Center.

Heinich, R. et al. (1996), 'Instructional Media and Technologies for Learning,' New Jersey: Prentice Hall, Inc.

Henderson, L. (1996), 'Instructional design of interactive multimedia,' Educational technology research And Development, 44(4): 85-104.

Hermans, R., Tondeur, J., van Braak, J., \& Valcke, M. (2008), 'The impact of primary school teachers' educational beliefs on the classroom use of computers,' Computers \& Education, 51(4): 1499-1509.

Holman, D. (2000), 'Contemporary Models of Management Education in the UK,' Management Learning, 31, 197217.

Hopkin, A. G. (1997), 'Staff Perspectives on Teaching and Learning Styles in Teacher Education in Botswana,' Journal of the International Society for Teacher Education, 1(1): 1-11.

Hopkins, P. D. (ed. 1998), 'Sex/Machine,' Bloomington: Indiana University Press.

Huang, H. M., \& Liaw, S. S. (2005), 'Exploring users' attitudes and intentions toward the Web as a survey tool,' Computers in Human Behavior, 21(5): 729-743.

Huang, I. (1997), 'Science education in Asia,' Frontier: The Interdisciplinary Journal of Study Abroad, 3(2): 13-24.

Inan, F. A., Lowther, D. L., Ross, S. M., \& Strahl, D. (2010), 'Pattern of classroom activities during students' use of computers: relations between instructional strategies and computer applications,' Teaching and Teacher Education, 26(3): 540-546.

Iniesta-Bonillo, M.A., Sánchez-Fernández, R., \& Schlesinger, W. (2013), 'Investigating factors that influence on ICT usage in higher education: a descriptive analysis,' International Review on Public and Nonprofit Marketing, 10(2): $163-174$. 
Khan, M.A., Omrane, A., \& Rodriguez, A. M. (2017). A Theoretical Analysis of Factors Influencing the Decision of Faculty to Use Educational Technologies in the Context of Institutions of Higher Education. Advances in Social Sciences Research Journal, 4(1) $147-164$.

Katz, R. (2006), 'The ECAR study of undergraduate students and information technology,' Retrieved from, http://www.educause.edu/ir/library/pdf/ers0607/ERS0607w.pdf.

Keengwe, J., \& Onchwari, G. (2008), 'Computer technology integration and student learning: Barriers and promise,' Journal of Science Education and Technology, 17, 560- 565.

Kelley, P. \& Maushak, N. (2004), 'Teaching Online: Hints from the Trenches, Distance Learning: A magazine for leaders,' International Journal of Education and Development using Information and Communication Technology, 9(1):112-125.

Khan, M. A. \& Law, S. L. (2015), 'An Integrative Approach to Curriculum Development in Higher Education in the USA: A Theoretical Framework,' International Education Studies, 8(3).

Kim, M. C., \& Hannafin, M. J. (2011), 'Scaffolding problem solving in technology-enhanced learning environments (TELEs): bridging research and theory with practice,' Computers \& Education, 56(2): 403-417.

Lee, P.-Y. (2009), 'Strategy training for Taiwanese learners: a handbook,' Retrieved from http://csuchicodspace.calstate.edu/handle/10211.4/141.

Leedy, P. (1989), 'Practical research: Planning and design (4th ed.),' New York.

Li, Q. (2007), 'Student and teacher views about technology: a tale of two cities? Journal of Research on Technology in Education, 39(4): 377-397.

Lim, C. P., \& Chai, C. S. (2008), 'Teachers' pedagogical beliefs and their planning and conduct of computermediated classroom,' British Journal of Educational Technology, 39(5), 807-828

Liu, K.-H. (2007), 'Teaching digital art in art teacher education: recommendations for Taiwanese pre-service elementary art teachers in the digital age,' Unpublished master's thesis, Columbia University.

Liu, S.-H. (2010), 'Correlation between teachers' pedagogical beliefs and teaching activities on technology integration,' In: Global learn Asia Pacific 2010-Global Conference on learning and technology. May 17-20, Penang, Malaysia.

Liu, Y. \& Szabo, Z., (2009), 'Teachers' attitudes toward technology integration in schools: A four year study,' Teachers and Teaching: Theory and Practice, 15, 5-23.

Lumpe, A. T., \& Chambers, E. (2001), 'Assessing teachers' context beliefs about technology use,' Journal of Research on Technology in Education, 34(1): 93.

Macleod H., Haywood, D., Haywood, J. and Anderson C. (2002), 'Gender and Information and Communications Technology - a 10-year study of new undergraduates,'TechTrends, 46 (6).

Martin, M. (1991), 'Hello, Central: Gender, technology and culture in the formation of telephone systems. Montreal: McGill-Queens University Press.

Maushak, N. J., Kelley, P., \& Blodgett, T. (2001), 'Preparing teachers for the inclusive classroom: A preliminary study of attitudes and knowledge of assistive technology,' Journal of Technology and Teacher Education, 9(3): 419-431.

McCannon, M., \& Crews, B.T. (2000), 'Assessing the technology training needs of elementary school teachers,' Journal of Technology and Teacher Education, 8(2): 111-121.

Medlin, B. D. (2001), 'The Factors That May Influence a Faculty Member's Decision to Adopt Electronic Technologies in Instruction, Dissertation submitted to the Faculty of the Virginia Polytechnic Institute and State University.

Middleton, B. M., \& Murray, R. K. (1999), 'The impact of instructional technology on student academic achievement in reading and mathematics,' International Journal of Instructional Media, 26, 109-116.

Mumtaz, S. (2000), 'Factors affecting teachers' use of information and communications technology: a review of the literature, Journal of Information Technology for Teacher Education, 9(3): 319-342.

Neyland, E. (2011), 'Integrating online learning in NSW secondary schools: Three schools perspectives on ICT adoption,' Australia Journal of Educational Technology, 27(1):152-173

Niederhauser, D. S., \& Stoddart, T. (2001), 'Teachers' instructional perspectives and use of educational software,' Teaching and Teacher Education, 17(1): 15-31. 
Nussbaum, M., Alvarez, C., McFarlane, A., Gomez, F., Claro, S., \& Radovic, D. (2009), Technology as small group faceto-face Collaborative Scaffolding,' Computers \& Education, 52(1): 147-153.

Oblinger, D. G., \& Maruyama, M. K. (1996), 'Distributed learning (CAUSE Professional Paper Series, \#14). Boulder, CO: CAUSE.

Osika, E. (2006), 'The concentric support model: A model for the planning and evaluation of distance learning programs,' Online Journal of Distance Learning Administration, 9(3). Retrieved from http://www.westga.edu/ distance/ojdla/fall93/osika93.pdf/.

Osika, E. R., \& Buteau, R., (N/A), 'Factors Influencing Faculty Use of Technology in Online Instruction: A Case Study,' Retrieved from http://www.westga.edu/ distance/ojdla/spring121/osika121.html

Panici, D.A. (1998), 'New Media and the Introductory Mass Communication Course,' Journalism and Mass Communication Educator, 53(1), 52-63.

Park, C. N., \& Son, J.B. (2009), 'Implementing computer-assisted language learning in the EFL classroom: teachers' perceptions and perspectives,' International Journal of Pedagogies \& Learning, 5(2): 80-101.

Peluchette, J. V. \& Rust, K. A. (2005), 'Technology Use in the Classroom: Preferences of Management Faculty Members,' Journal of Education for Business, 80(4): 200-2006.

Plair, S. (2008), 'Revamping professional development for technology integration Factors influencing teachers' adoption and integration of ICT and fluency,' The clearing house, 82(2): 70-74.

Reeves, T., \& Reeves, P. (1993), 'Effective dimensions of interactive learning on the World Wide Web, In B. Khan (Eds.), Webbased instruction (pp. 59-66). Englewood Cliffs, New Jersey: Educational Technology Publications.

Rice, M. L. \& Miller, M. T. (2001), 'Faculty involvement in planning for the use and integration of instructional and administrative technologies,' Journal of Research on Computing in Education, 33(3), 328-336.

Richey, R.C. (2008), 'Reflections on the 2008 AECT Definitions of the Field,' TechTrends, 52(1): 24-25.

Robertson, S. I., Calder, J., Fung, P., Jones, A., O’Shea, T. \& Lambrechts, G. (1996), 'Pupils, Teachers and Palmtop Computers,' Journal of Computer Assisted Learning, 12, 194-204.

Schiller, J. (2003), 'Working with ICT Perceptions of Australian Principals,' Journal of Educational Administration, 41(2): 171-185.

Schumacher, P., \& Morahan, M. J. (2001), 'Gender, internet, and computer attitudes \& experiences,' Computers in Human Behavior, 17 (1): 95-110.

Seay. R.. Rudolph. H., \& Chamberlain. D. (2001), 'Faculty perceptions of interactive television instruction,' Journal of Education for Business, 77(2): 99-106.

See, J. (1994), 'Technology and Outcome-Based Education: Connections in Concept and Practice. The Computing Teacher, 17(3): 30-31.

Shashaani, L. (1995), 'Gender differences in mathematics experience and attitude and their relation to computer attitude,' Educational Technology, 35(3), 32-38.

Sherry, L., \& Gibson, D. (2002), 'The path to teacher leadership in educational technology. Contemporary issues in technology and teacher education, 2(2): 178-203.

Snelbecker, G. E. (1999), 'Some thoughts about theories, perfection and instruction. In C.

Reigeluth Mahwah (Ed.), Instructional-design theories and models. New Jersey/London: Lawrence Erlbaum.

Spotts, T. (1999), 'Faculty use of instructional technology in higher education: Profiles of contributing and deterring factors,' Dissertation Abstracts International section A: Humanities and Social Sciences, 59(10-A): 3738.

Spotts, T., Bowman, M., \& Mertz, C. (1997), 'Gender and use of instructional technologies: A study of university faculty,' Higher Education, 54(4): 421-436.

Stockdill, S.H., \& Morehouse, D. L. (1992), 'Critical factors in the successful adoption of technology: A checklist based on the findings,' Educational Technology, 32(1): 57-58.

Tezci, E., (2011a), 'Factors that influence preservice teachers' ICT usage in education,' European Journal of Teacher Education, 34,483-499. 
Khan, M.A., Omrane, A., \& Rodriguez, A. M. (2017). A Theoretical Analysis of Factors Influencing the Decision of Faculty to Use Educational Technologies in the Context of Institutions of Higher Education. Advances in Social Sciences Research Journal, 4(1) $147-164$.

Thieman, G. Y. (2008), 'Using technology as a tool for learning and developing 21st centurycitizenship skills: An examination of the NETS and technology use by preservice teachers with their K-12 students,' Contemporary Issues in Technology and Teacher Education, 8(4): 342-366.

Tomei, L. A. (2005), 'Taxonomy for the technology domain,' USA: Information Science Publishing.

Tondeur, J., van Keer, H., van Braak, J., \& Valcke, M. (2008), 'ICT integration in the classroom: challenging the potential of a school policy,' Computers \& Education, 51(1): 212-223.

Trucano, M. (2005), 'Knowledge maps: ICTs in educations, Washington, DC: InfoDev/WorldBank

Twigg, C. A., \& D. G. Oblinger. (1997), 'The Virtual University,' Washington, D.C.: EDUCOM. http://www.educause/. Ulrich T. A. (2005), 'The Relationship of Business Major to Pedagogical Strategies,' Journal of Education for Business, 80 (5): 269-275.

Usun, S. (2005), 'A Model Proposal for Instructional Technology and Multimedia Center for Faculty of Education,' The Turkish Online Journal of Educational Technology, 4 (4): 2.

Vance, C. M. (1993), 'Mastering Management Education: Innovations in Teaching Effectiveness,' Newbury Park, CA: Sage.

Vannatta, R. \& Fordham, N. (2004), 'Teacher dispositions as predictors of classroom technology use,' Journal of Research on Technology in Education, 36(3): 253-271.

Vannatta, R. A. (2000), 'Integrating, infusing, modeling: Preparing technology using educators,' Journal of Computing in Teacher Education, 16(2), 6-14.

Venkatesh, V., \&Morris, M. G. (2000), 'Why don't men ever stop to ask for directions? Gender, social influence, and their role in technology acceptance and usage behavior,' MIS Quarterly, 24(1): 115-139.

Vodanovieh. S. \& Piotrowski. C. ( l'W9), 'Views of academic I-O psychologists toward Internetbased instruction,' The Industrial-Orgatuziuiontil Pxychologist, 370, 52-55.

Voogt, J. (2003), 'Consequences of ICT for Aims, Contents, Processes and Environments of Learning,' In J. van den Akker, W. Kuiper, \& U. Hameyer (Eds.), Curriculum landscapes and trends (blz. 217-236). Dordrecht: Kluwer

Wajcman, Judy. (1991), 'Feminism confronts technology,' Cambridge: Polity Press.

Waldeck, J. H., Kearney, P., \& Plax, T. G. (2001), 'Instructional and developmental communication theory and research in the 1990s: Extending the agenda for the 21st century,' In

W. Gudykunst (Ed.), Communication yearbook 24 (pp. 207_229), Thousand Oaks, CA: Sage.

Webber, C. (2003), 'Introduction New Technologies and Educative Leadership,' Journal of Educational Administration, 41(2): 119-123

Weston, C., \& Cranton, P. A. (1986), 'Selecting instructional strategies,' Journal of Higher Education, 57, $259-288$.

Witt, P. L, \& Wheeless, L. R. (2001), 'An experimental study of teachers' verbal and nonverbal immediacy and students' affective and cognitive learning,' Communication Education, 50, 327-342.

Wozney, L., Venkatesh, V., \& Abrami, P.C. (2006), 'Implementing computer technologies: Teachers' perceptions and practices,' Journal of Technology and Teacher Education, 14(1): 173-207.

Yen, J.-C., \& Lee, C.-Y. (2011), 'Exploring problem solving patterns and their impact on learning achievement in a blended learning environment,' Computers \& Education, 56(1): 138-145.

Yildirim, S., (2007), 'Current utilization of ICT in Turkish basic education schools: A review of teachers' ICT use and barriers to integration,' International Journal of Instructional Media, 34, 171-186.

Zare-ee, A. A. (2011), 'University Teachers' Views on the use of Information Communication Technologies in Teaching and Research,' The Turkish Online Journal of Educational Technology, 10(3). 